\title{
X-RAY DIFFERACTION ANALYSIS FOR THE INTERPRETATION OF CLAY MINERALS PARAGENESIS IN THE NEOGENE SEDIMENTS OF MANG AND VICINITY, SUB- HIMALAYAS, PAKISTAN
}

\author{
Muhammad Yasin*, Muhammad Ibrahim \\ *Institute of Geology, University of Azad Jammu and Kashmir, Muzaffarabad, Pakistan \\ ${ }^{1}$ Plant operator at Fauji Fertilizer Company Limited, Pakistan. \\ *Corresponding Author: Rajayasinkhan@gmail.com
}

This is an open access article distributed under the Creative Commons Attribution License, which permits unrestricted use, distribution, and reproduction in any medium, provided the original work is properly cited

\section{ARTICLE DETAILS}

\section{Article history:}

Received 24 October 2016

Accepted 7 December 2016

Available online 3 January 2017

Keywords:

Interpreted, Paragenesis,

diffractometer, climes, epizonal.

\section{ABSTRACT}

The Neogene sediments were interpreted to understand the clay mineral paragenesis in rocks using x-ray differaction technique. The process was conducted with an x-ray diffractometer, Anode $=\mathrm{Cu}(\mathrm{Cu} \mathrm{K} \alpha=$ $1.541871 \AA$ ) , Filter $=\mathrm{Ni}$, Current $=15 \mathrm{~mA}$ and Voltage $=35 \mathrm{kv}$. The clay mineral assemblages in the rocks indicates that the neogene sediments were derived from the preexisting sedimentary, metasedimentary, metamorphics and igneous rocks and formed in different climes in the continental environment. The illite crystallinity (IC) value $\left(0.2165 \Delta^{\circ} 2 \theta \mathrm{CuK} \alpha\right)$ in the area correspond exactly with the epizonal metamorphic conditions.

\section{Introduction}

The X-ray differaction analysis of Neogene sediments was carried out in the Mang and adjoining areas at latitude $33^{\circ} 45^{\prime} 00^{\prime \prime} \mathrm{N}$ to $33^{\circ} 51^{\prime} 30^{\prime \prime} \mathrm{N}$ and Longitude $73^{\circ} 35^{\prime} 36^{\prime \prime} \mathrm{E}$ to $73^{\circ} 45^{\prime} 00^{\prime \prime} \mathrm{E}$, the area being shown on toposheet No. 43/G-9, Survey of Pakistan (Yasin, 2014), in the SubHimalayan Foreland basin of Pakistan. The Murree and Nagri Formations among Neogene sediments were selected for X-ray differaction analysis.

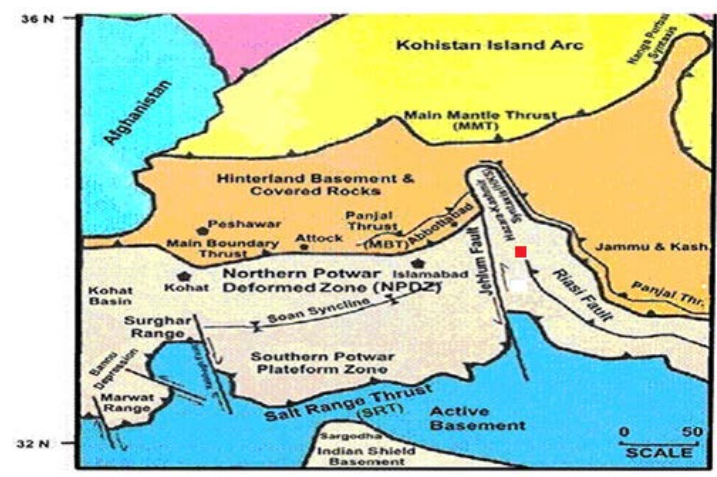

Figure 1. The northwestern Himalayas of Pakistan displayed on the tectonic map (after Baig and Lawrence, 1987; Monalisa and Khawaja, 2004). The location of the project area being shown by a rectangle.

\section{Previous work}

The geology of the region was studied by different workers (Wadia, 1928; Ashraf and Chaudhary, 1984). However, the present work deals with the first comprehensive study of the area using X-ray differaction analysis.

\section{Geological setting}

The Himalayan orogen was formed about 55 Ma ago during Indo-Eurasian collision. About 30 to $40 \mathrm{Ma}$ ago the rocks were metamorphosed during crustal thickening and about $20 \mathrm{Ma}$ ago during granitic melting some movement along the South Tibet Detachment Zone has been observed
(Garzanti et al., 2006). The continuous convergence propelled the thrust belt towards the south. During middle to late Miocene or early Pliocene times the Main Boundary Thrust (MBT) was active and thrusted the lesser Himalayan zone over Sub-Himalaya (Garzanti et al., 2006). At present times the Main Boundary Thrust (MBT) separates Lesser Himalayan zone above from the Tertiary Foreland Neogene sedimentary basin below. The material in the Foreland basin was deposited by means of distributary channels. Among these sediments the clays and shale are inundated stream (flood plain) deposits.

The mountains in the remote recesses as observed in the project area are known for their serene heights, arduous ascents and calmness in solitude (Yasin, 2014). They are also precipitous in places. The Jassa Pir peak with an altitude of over $216,3 \mathrm{~m}$ has few sublime influences. Furthermore, the snowy scalps are pinnacled in mist and cloud and the area is very bleak in winter. However, the countryside is extremely parched by the sun during summer. The most alluring and captivating landscapes are also possessed by the area.

\section{Methodology}

In order to understand the paragenesis, eight rock samples of clays and shale $(C-1, C-2, C-4, C-5, C-7,2014)$. The $x$-ray differaction analysis of the clays and shales was carried out in the Chemistry Department, Quaid-eAazam University, Islamabad, Pakistan. The results were further interpreted at the petrology Laboratory, University of Azad Jammu and Kashmir, Muzaffarabad, Pakistan. In x-ray differaction analysis the samples were first ground into fine powder, mounted on the slides before bombarding with the x-rays. The XRD analyses was conducted with an x-ray diffractometer, Anode $=\mathrm{Cu}(\mathrm{Cu} \mathrm{K \alpha}=1.541871 \AA$ ) $)$, Filter = $\mathrm{Ni}$, Current $=15 \mathrm{~mA}$ and Voltage $=35 \mathrm{kv}$. The X-ray differaction analysis commonly governed by the differaction of rays within the body of material revealed acute remarks on mineralogy and illite crystallinity. The diagnostic peaks on the chart differactogram are the illustrations of the relation of the intensity versus differaction angle on $\mathrm{X}$ and $\mathrm{Y}$-axis respectively (Figs. 2 to 9).

\section{Results and Discussions}

5.1 X-Ray Differaction Analysis of Clays And Shales 
The Neogene rock samples according to the geological classifications belong to the Murree and Nagri Formations.

The mineral assemblage in the rock samples of Murree rock Formation as identified through the differactogram includes illite, quartz, corrensite regular interstratified chlorite-montmorillonite, plagioclase feldsparalbite, smectite montmorillonite, muscovite, calcite, aragonite, siderite, kaolinite, dolomite, chlorite thuringite, gypsum, rectorite regular interstratified chlorite-montmorillonite, chlorite penninite, pyrite, goethite, alkali feldspar orthoclase, smectite saponite and lepidocrocite.

The mineral assemblage in the rock samples of Nagri rock Formation as identified through the differactogram includes illite, quartz, corrensite regular interstratified chlorite-montmorillonite, plagioclase feldsparalbite, calcite, aragonite, smectite saponite, siderite, pyrite, goethite, chlorite thuringite, haematite, smectite montmorrilonite lepidocrocite, rectorite-regular interstratified mica-montmorillonite, gypsum, plagioclase feldspar-albite, chlorite penninite, muscovite, haematite and dolomite.

The results have been enumerated under the tables 1 to 8 and plotted on the figures 2 to 9 .

The illite crystallinity is measured in the rock samples (C-8 \& C-2) collected from the northeastern and southwestern part of the study area (Yasin, 2014) respectively. The illite crystallinity (IC) value of $0.2165 \Delta^{\circ}$ $2 \theta \mathrm{CuK \alpha}$ (Fig. 10) in the area correspond exactly with the epizonal metamorphic conditions (Kubler, 1967, 68, 84). It can be elicited through the research that the (IC) value of $0.2165 \Delta^{\circ} 2 \theta \mathrm{CuK \alpha}$ remained uniform in both of the formations exposed towards the northeastern and southwestern part of the study area (Fig. 10, Fig.11).

Table. 1: Showing the mineralogical composition of Nagri clays (Sample No. C-1).

\begin{tabular}{|l|l|l|l|l|l|l|l|}
\hline $\begin{array}{l}\text { Peak } \\
\text { No. }\end{array}$ & $\begin{array}{l}\text { Identified } \\
\text { Minerals }\end{array}$ & $\begin{array}{l}\text { Pos.[2th } \\
\text { value } \\
\text { calculated }\end{array}$ & $\begin{array}{l}\text { Pos.[2th } \\
\text { Original } \\
\text { value }\end{array}$ & $\begin{array}{l}\text { d-spacing } \\
\text { Value } \\
\text { calculated }\end{array}$ & $\begin{array}{l}\text { d-spacing } \\
\text { Original } \\
\text { value }\end{array}$ & FWHM & $\begin{array}{l}\text { Intensity } \\
\%\end{array}$ \\
\hline 1 & Illite & 19.8844 & 19.82 & 4.46519 & 4.48 & 0.2362 & 6.51 \\
\hline 2 & Quartz & 20.9076 & 20.85 & 4.24892 & 4.26 & 0.0787 & 17.27 \\
\hline 3 & Corrensite & 25.2109 & 25.23 & 3.53258 & 3.53 & 0.6298 & 2.07 \\
\hline 4 & Quartz & 26.6767 & 26.67 & 3.34172 & 3.343 & 0.1181 & 100 \\
\hline 5 & Albite & 27.9021 & 27.92 & 3.19768 & 3.196 & 0.2362 & 6.41 \\
\hline 6 & Calcite & 29.4668 & 29.43 & 3.03134 & 3.035 & 0.0984 & 14.89 \\
\hline 7 & Aragonite & 33.2192 & 33.18 & 2.69701 & 2.700 & 0.4723 & 2.69 \\
\hline 8 & $\begin{array}{l}\text { Smectite } \\
\text { Saponite }\end{array}$ & 35.011 & 35.05 & 2.56298 & 2.56 & 0.3149 & 8.79 \\
\hline 9 & Quartz & 36.5801 & 36.56 & 2.45656 & 2.458 & 0.1574 & 9.1 \\
\hline \hline 10 & Quartz & 39.503 & 39.49 & 2.28128 & 2.282 & 0.059 & 9.93 \\
\hline 11 & Siderite & 42.5025 & 42.44 & 2.12697 & 2.13 & 0.1574 & 6.2 \\
\hline 12 & Aragonite & 45.6601 & 45.90 & 1.98696 & 1.977 & 0.7872 & 2.48 \\
\hline 13 & Calcite & 48.5902 & 48.55 & 1.87377 & 1.875 & 0.2362 & 3.52 \\
\hline 14 & Quartz & 50.1589 & 50.21 & 1.81879 & 1.817 & 0.0787 & 10.13 \\
\hline 15 & Pyrite & 55.3242 & 56.34 & 1.66059 & 1.633 & 0.9446 & 1.45 \\
\hline 16 & Quartz & 59.9875 & 60.03 & 1.54089 & 1.541 & 0.072 & 6.2 \\
\hline 17 & Dolomite & 68.2957 & 67.42 & 1.37227 & 1.389 & 0.384 & 5.48 \\
\hline & & & & & & & \\
\hline
\end{tabular}

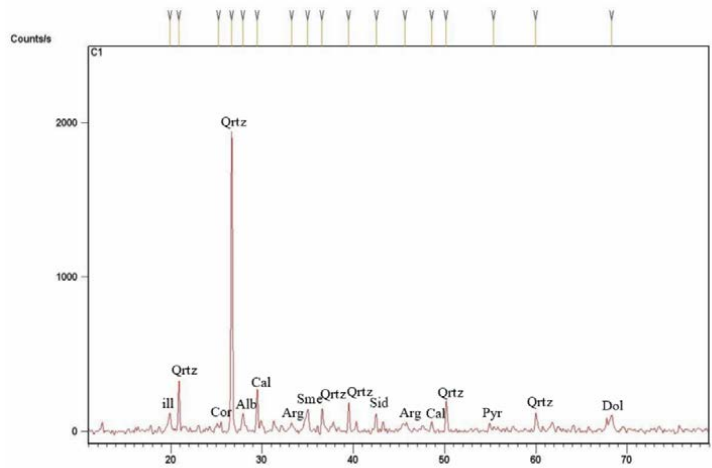

Fig. 2: Showing diffractogram of Nagri clays. ill = illite, $Q$ rtz $=$ Quartz, Cor $=$ Corrensite, $\mathrm{Alb}=$ Albite, $\mathrm{Cal}=$ Calcite, $\mathrm{Arg}=$ Aragonite, Sme $=$ Smectite, Sid $=$ Siderite, Pyr $=$ Pyrite .

Table. 2: Showing mineralogical composition of Nagri clays (Sample No. C-2).

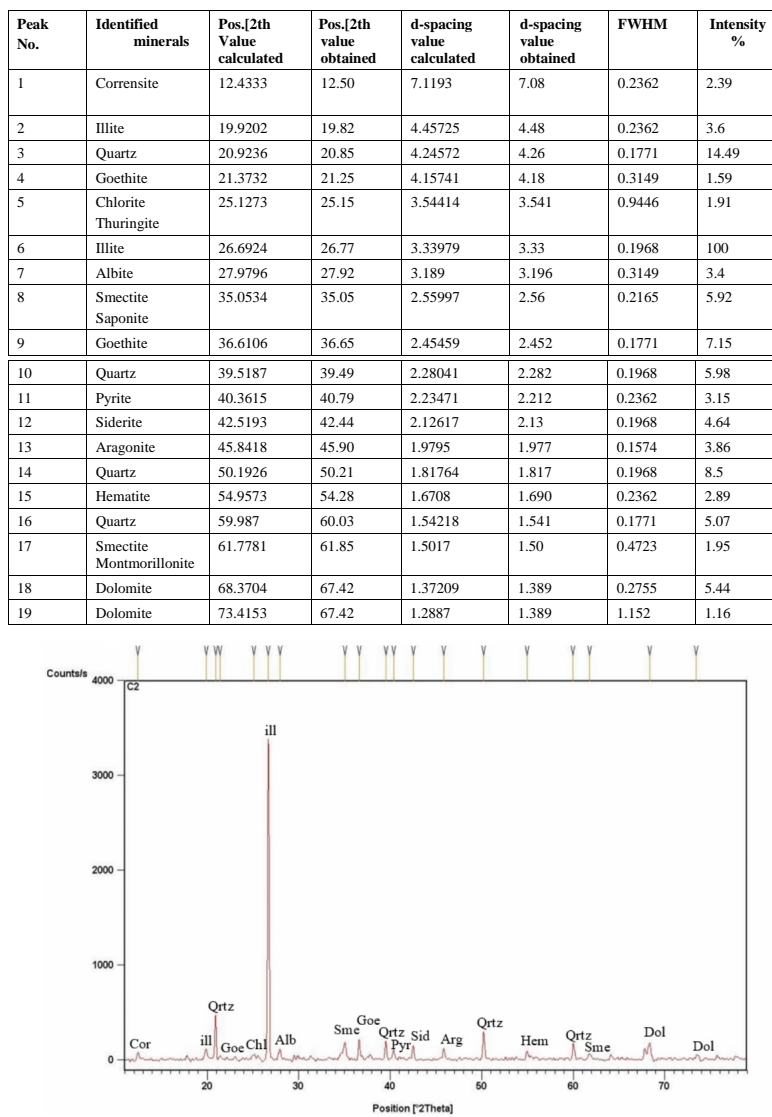

Fig. 3: Showing diffractogram of Nagri clays. Cor $=$ Corrensite, ill $=$ illite, Qrtz $=$ Quartz, Goe $=$ Goethite, $\mathrm{Chl}=$ Chlorite, Alb $=$ Albite, Sme = Smectite, $\mathrm{Pyr}=$ Pyrite, $\mathrm{Sid}=$ Siderite, $\mathrm{Arg}=$ Aragonite, $\mathrm{Hem}=$ Hematite, Dol $=$ Dolomite

Table 3: Showing mineralogical composition of Murree shale (Sample No. C-4).

\begin{tabular}{|l|l|l|l|l|l|l|l|}
\hline Peak No. & $\begin{array}{l}\text { Identified } \\
\text { Minerals }\end{array}$ & $\begin{array}{c}\text { Pos.[2th } \\
\text { Calculat- } \\
\text { ed Values }\end{array}$ & $\begin{array}{c}\text { Pos.[2th } \\
\text { Standard } \\
\text { values }\end{array}$ & $\begin{array}{c}\text { d-spacing } \\
\text { Calculated } \\
\text { Values }\end{array}$ & $\begin{array}{c}\text { d-spacing } \\
\text { Standard } \\
\text { values }\end{array}$ & FWHM & Intensity \% \\
\hline 1 & Illite & 19.82 & 19.808 & 4.48 & 4.48386 & 0.2362 & 7.63 \\
\hline 2 & Quartz & 20.85 & 20.894 & 4.26 & 4.25166 & 0.1181 & 16.98 \\
\hline 3 & Corrensite & 25.23 & 25.3976 & 3.53 & 3.50703 & 0.4723 & 2.88 \\
\hline 4 & Quartz & 26.67 & 26.6695 & 3.343 & 3.3426 & 0.1378 & 100 \\
\hline 5 & $\begin{array}{l}\text { Plagioclase } \\
\text { feldspar-Albite }\end{array}$ & 27.92 & 27.911 & 3.196 & 3.19668 & 0.2362 & 4.75 \\
\hline 6 & $\begin{array}{l}\text { Smectite } \\
\text { Montmorillon-ite }\end{array}$ & 29.58 & 29.4663 & 3.02 & 3.0314 & 0.1378 & 59.42 \\
\hline 7 & Muscovite & 35.00 & 34.9909 & 2.564 & 2.5644 & 0.1968 & 11.65 \\
\hline 8 & Calcite & 36.00 & 36.0826 & 2.495 & 2.48928 & 0.1574 & 9.64 \\
\hline 9 & Quartz & 36.56 & 36.583 & 2.458 & 2.45637 & 0.1181 & 10.22 \\
\hline 10 & Aragonite & 37.93 & 37.7091 & 2.372 & 2.38557 & 0.3149 & 4.89 \\
\hline 11 & Quartz & 39.49 & 39.4873 & 2.282 & 2.28214 & 0.059 & 17.99 \\
\hline 12 & Siderite & 42.44 & 42.4244 & 2.13 & 2.1307 & 0.4723 & 6.33 \\
\hline 13 & Calcite & 43.18 & 43.237 & 2.095 & 2.09252 & 0.2362 & 9.64 \\
\hline 14 & Aragonite & 45.90 & 45.6979 & 1.977 & 1.9854 & 0.7872 & 2.01 \\
\hline
\end{tabular}

Table. 4: Showing mineralogical composition of Nagri clays (Sample No. C-5).

\begin{tabular}{|l|l|l|l|l|l|l|l|}
\hline PeakNo. & $\begin{array}{l}\text { Identified } \\
\text { Minerals }\end{array}$ & $\begin{array}{l}\text { Pos.[2th } \\
\text { Calculated } \\
\text { value } \\
\text { s }\end{array}$ & $\begin{array}{c}\text { Pos.[2th } \\
\text { standard } \\
\text { values }\end{array}$ & $\begin{array}{l}\text { d-spacing } \\
\text { Calculated } \\
\text { values }\end{array}$ & $\begin{array}{c}\text { d-spacing } \\
\text { Standar } \\
\text { d values }\end{array}$ & FWHM & $\begin{array}{l}\text { Intensity } \\
\%\end{array}$ \\
\hline 1 & Illite & 19.87 & 19.82 & 4.4684 & 4.48 & 0.3149 & 5.24 \\
\hline 2 & Quartz & 20.908 & 20.85 & 4.24884 & 4.26 & 0.0787 & 16.87 \\
\hline 3 & Quartz & 26.691 & 26.67 & 3.33995 & 3.343 & 0.1181 & 100 \\
\hline 4 & Lepidocrocite & 27.8725 & 27.10 & 3.201 & 3.29 & 0.2362 & 4.99 \\
\hline 5 & $\begin{array}{l}\text { Smectite } \\
\text { Saponite }\end{array}$ & 35.0344 & 35.05 & 2.56132 & 2.56 & 0.1181 & 9.73 \\
\hline 6 & Quartz & 36.5771 & 36.56 & 2.45676 & 2.458 & 0.0787 & 9.73 \\
\hline 7 & Aragonite & 37.7668 & 37.93 & 2.38206 & 2.372 & 0.4723 & 2.65 \\
\hline 8 & Quartz & 39.5061 & 39.49 & 2.2811 & 2.282 & 0.059 & 7.23 \\
\hline 9 & Pyrite & 40.3607 & 40.79 & 2.23476 & 2.212 & 0.1181 & 4.41 \\
\hline 10 & Siderite & 42.5201 & 42.44 & 2.12613 & 2.13 & 0.1574 & 6.65 \\
\hline 11 & Aragonite & 45.8686 & 45.90 & 1.97841 & 1.977 & 0.2362 & 3.99 \\
\hline
\end{tabular}


Cite this article as: Muhammad Yasin*, Muhammad Ibrahim ${ }^{1} \mathrm{X}$-Ray Differaction Analysis For The Interpretation of Clay Minerals

\begin{tabular}{|l|l|l|l|l|l|l|l|}
\hline 12 & Quartz & 50.1751 & 50.21 & 1.81673 & 1.817 & 0.072 & 10.72 \\
\hline 13 & Quartz & 50.3234 & 50.21 & 1.81622 & 1.817 & 0.072 & 5.65 \\
\hline 14 & Hematite & 54.9046 & 54.28 & 1.67089 & 1.690 & 0.144 & 3.66 \\
\hline 15 & Quartz & 59.993 & 60.03 & 1.54076 & 1.541 & 0.12 & 7.98 \\
\hline 16 & $\begin{array}{l}\text { Smectite } \\
\text { Montmorilloite }\end{array}$ & 61.8195 & 61.85 & 1.49955 & 1.50 & 0.384 & 3.66 \\
\hline 17 & Hematite & 64.1026 & 64.14 & 1.45154 & 1.452 & 0.576 & 2 \\
\hline 18 & Dolomite & 68.3164 & 67.42 & 1.37191 & 1.389 & 0.384 & 5.82 \\
\hline 19 & Dolomite & 75.7376 & 67.42 & 1.25485 & 1.389 & 0.288 & 2.49 \\
\hline
\end{tabular}

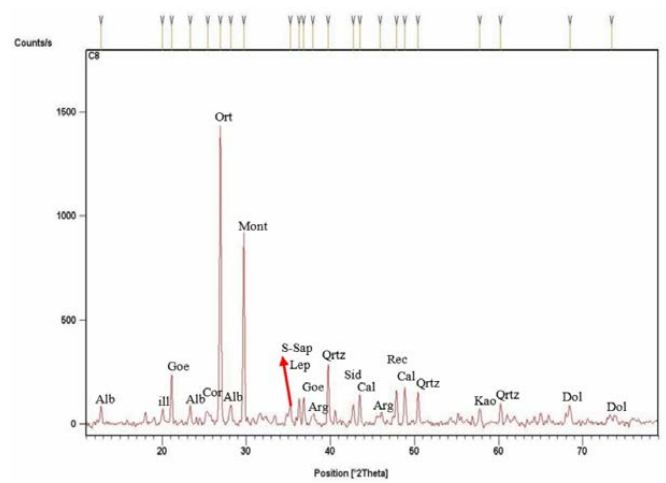

\begin{tabular}{|l|l|l|l|l|l|l|l|}
\hline $\begin{array}{l}\text { Peak } \\
\text { No. }\end{array}$ & $\begin{array}{l}\text { Identified } \\
\text { Minerals }\end{array}$ & $\begin{array}{c}\text { Pos.2th } \\
\text { Calculated } \\
\text { values }\end{array}$ & $\begin{array}{c}\text { Pos.[2th } \\
\text { Standar } \\
\text { d values }\end{array}$ & $\begin{array}{c}\text { d-spacing } \\
\text { Calculated } \\
\text { values }\end{array}$ & $\begin{array}{c}\text { d-spacing } \\
\text { Standar } \\
\text { d values }\end{array}$ & FWHM & Intensity \% \\
\hline 1 & Illite & 19.8367 & 19.82 & 4.47584 & 4.48 & 0.3149 & 7.55 \\
\hline 2 & Quartz & 20.9116 & 20.85 & 4.24813 & 4.26 & 0.0787 & 13.5 \\
\hline 3 & Albite & 23.1026 & 23.54 & 3.84996 & 3.78 & 0.2362 & 5.37 \\
\hline 4 & Illite & 26.7048 & 26.77 & 3.33827 & 3.33 & 0.1181 & 100 \\
\hline 5 & Lepidocrocite & 27.8016 & 27.10 & 3.20901 & 3.29 & 0.4723 & 3.05 \\
\hline 6 & Calcite & 29.4719 & 29.43 & 3.03083 & 3.035 & 0.1181 & 45.28 \\
\hline 7 & Chlorite Penninite & 35.0381 & 35.05 & 2.56105 & 2.56 & 0.551 & 11.76 \\
\hline 8 & Aragonite & 36.0499 & 36.21 & 2.49147 & 2.481 & 0.2362 & 6.82 \\
\hline 9 & Quartz & 36.5871 & 36.56 & 2.45611 & 2.458 & 0.1181 & 10.01 \\
\hline 10 & Quartz & 39.5101 & 39.49 & 2.28088 & 2.282 & 0.1574 & 16.26 \\
\hline 11 & Siderite & 42.504 & 42.44 & 2.1269 & 2.13 & 0.1181 & 7.55 \\
\hline 12 & Calcite & 43.2841 & 43.18 & 2.09036 & 2.095 & 0.1968 & 10.6 \\
\hline 13 & Aragonite & 45.7223 & 45.90 & 1.9844 & 1.977 & 0.7872 & 3.63 \\
\hline 14 & Calcite & 47.5809 & 47.53 & 1.91113 & 1.913 & 0.1574 & 8.42 \\
\hline 15 & Calcite & 48.5783 & 48.55 & 1.8742 & 1.875 & 0.2362 & 7.26 \\
\hline 16 & Quartz & 50.1903 & 50.21 & 1.81772 & 1.817 & 0.1968 & 10.89 \\
\hline 17 & Quartz & 59.9856 & 60.03 & 1.54221 & 1.541 & 0.1181 & 7.98 \\
\hline 18 & Smectite & 61.7508 & 61.85 & 1.50229 & 1.50 & 0.4723 & 5.52 \\
\hline 19 & Montmorillonite & & & & & & \\
\hline 20 & Dolomite & 68.2894 & 67.42 & 1.37352 & 1.389 & 0.2362 & 7.26 \\
\hline & Dolomite & 73.2977 & 67.42 & 1.29048 & 1.389 & 1.152 & 1.45 \\
\hline
\end{tabular}

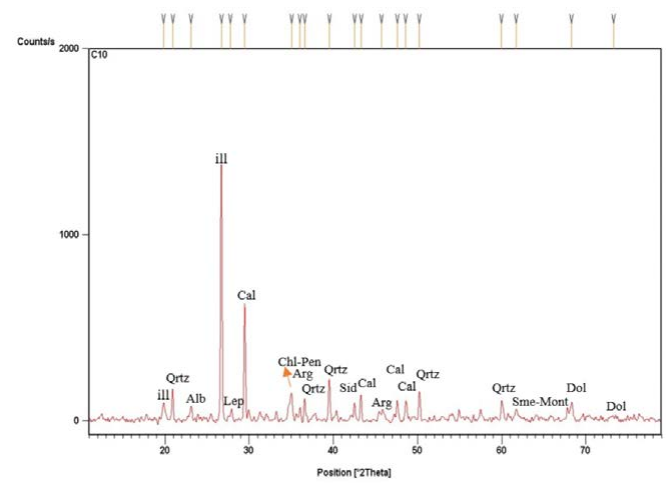

Fig. 7: Showing diffractogram of Murree clays. Alb $=$ Albite, ill $=$ illite, Goe $=$ Goethite, Cor $=$ Corrensite, Ort $=$ Orthoclase, Mont. $=$ Montmorillonite, S-Sap = Smectite Saponite, Lep $=$ Lepidocrocite, Goe $=$ Goethite, $\operatorname{Arg}=$ Aragonite, Sid $=$ Siderite, $\mathrm{Cal}=$ Calcite, $\mathrm{Rec}=$ Rectorite, Qrtz $=$ Quartz, Kao $=$ Kaolinite, Dol $=$ Dolomite .

Table. 7: Showing mineralogical composition of Nagri shale (Sample No. C-9).
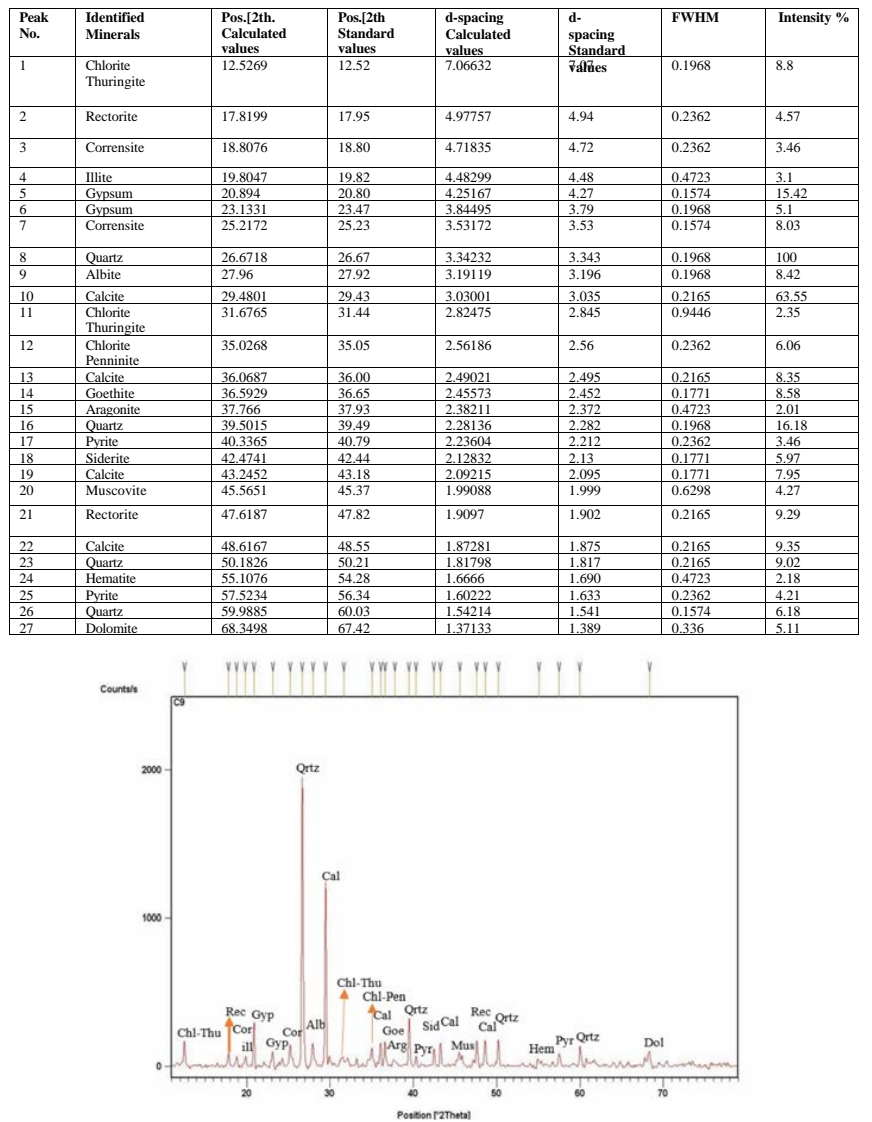

Fig. 8: Showing diffractogram of Nagri shale. Chl-Thu $=$ Chlorite Thuringite, Rec $=$ Rectorite, Cor $=$ Corrensite, ill = illite, Gyp = Gypsum, Qrtz $=$ Quartz, Cal $=$ Calcite, Chl-Pen $=$ Chlorite Penninite, Goe $=$ Goethite, $\mathrm{Arg}=$ Aragonite, $\mathrm{Pyr}=$ Pyrite, $\mathrm{Sid}=$ Siderite, Mus = Muscovite, Hem $=$ Haematite, Dol $=$ Dolomite .

Table. 8: Showing mineralogical composition of Murree clays (Sample No. C-10).

Fig. 9: Showing diffractogram of Murree clays. ill = illite, Qrtz = Quartz, $\mathrm{Alb}=$ Albite, Lep =Lepidocrocite,$\quad$ Cal = Calcite, Chl-Pen = Chlorite Penninite, $\operatorname{Arg}=$ Aragonite, Sid = Siderite, Sme-Mont $=$ Smectite Montmorillonite, Dol $=$ Dolomite.

\subsection{Clay Mineralogy}

The formation of illite in the Neogene sediments can be attributed to the decomposition of feldspar, deformation of muscovite and other diagenetic processes in a sedimentary environment (Deer et al., 1966). The alternate layers of two clay types (illite-smectite) are known as Rectorite (Hugget et al., 2001). The smectite in Neogene sediments is formed through neomorphism of soils and alteration of volcanic ash. The Corrensite (regular interstratified chlorite-montmorillonite) is sourced from the altered igneous rocks of basic composition and sandstone rock fragments (Hugget et al., 2001). The saponite exists in the mineral viens and basalt cavities (Deer et al., 1966). The basaltic rocks exposed in the area are Permian Panjal volcanics.

The albite and orthoclase are detrital in origin and are sourced from plutonic rocks and metamorphic rocks of green schist facies exposed in the Himalayan belt. The hematite, goethite and lepidochrocite indicate oxidizing conditions at the time of deposition of formation (Deer et al., 1966). The pyrite in the rock samples indicates that the reducing conditions exist in the part of basin. In Neogene sediments the calcite, aragonite, dolomite, pyrite, sulphur and quartz are found in association with gypsum. The limestone and dolomite are the fine grained detrital materials in the clays and shale. The coarse clasts of these rocks are present in sandstone (Yasin, 2014). The calcite, dolomite and gypsum in the rock could also exist through the pore water precipitation. The stratified rocks and hydrothermal minerals may act as the source material for siderite in the rock. The aragonite in the bulk composition is added from the agglutinated tests of organisms. The muscovite is sourced from regionally metamorphosed sediments, intermediate and acidic igneous rocks of the Himalayan mountains. Similarly, the chlorite is sourced from regionally metamorphosed sediments and hydrothermal alteration of pyroxene in mafic volcanic rocks (Deer et al., 1966). It is usually sourced from Al-rich hornblende in a reaction (Deer et al., 1966). The chlorites occur in metabasalts of Panjal volcanics. It also fills amygdules in Panjal volcanic rocks.

The clay minerals are detrital that retain their original character of source material, modified slightly in the depositional envireonment during diagenesis or neomorphism. The illite, montmorrilonite and illite-montmorrillonite are found in all depositional environments. Their alteration is common in fluviatile and subaerial environments. The chlorite forms authigenically in fresh water environment. The kaolinite is a dominant mineral in fluvial environment and hence own 
continental origin (Grim et al., 1949). Illite and chlorite are usually formed at very cold, hot and dry climate.

Illites, irregularly mixed layers, vermiculites and smectites are formed at temperate climatic conditions. Similarly the kaolinites are formed in subarid as well as hot wet climates (Hugget et al., 2001). The illite also remains stable at moderate climatic conditions and remains unaltered during fluvial transport over short distance while the presence of kaolinite in clays and shales indicates that the acidic conditions may prevail, organic matter may be present in the environment of deposition.

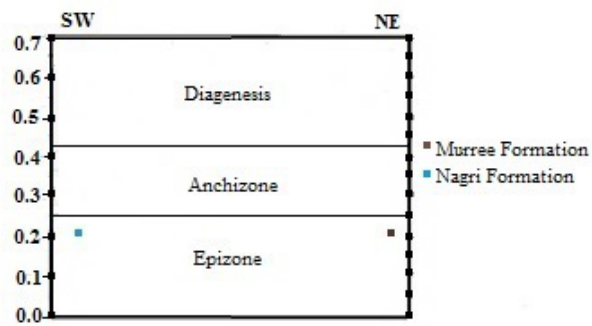

Fig. 10: Illite crystallinity $\left(0.2165 \Delta^{\circ} 2 \theta\right)$ in the Northeast and south west of the study area on a profile.

The Neogene sediments are deposited from the Mid Miocene to the Early Pleistocene (Chaudhri and Mahavir, 2012). The fold and thrust structures developed during tectonic activity increased the relief as well as erosion rate of hinterland (Chaudhri and Mahavir, 2012). As a result the sediments are deposited in the adjacent foredeep. The summer Monsoon is one of the significant factor that supplied sediments to the foreland basin (Saki et al., 2006).

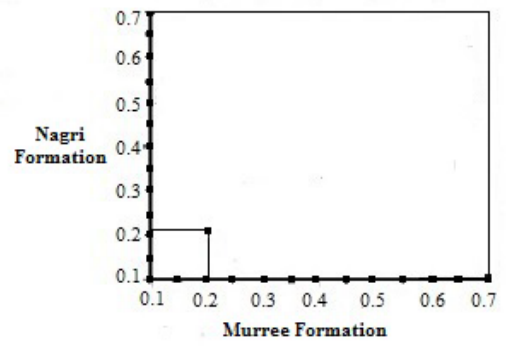

Fig. 11: The illite crystallinity value of the Nagri Formation and the Murree Formation coincides at $\left(0.2165 \Delta^{\circ} 2 \theta\right)$.

\section{Conclusion}

The study of Neogene sediments in the area indicates that the clay minerals were formed by the decompositions, deformations, alterations, neomorphism, pore water precipitations, authigenesis and other diagenetic processes at varied climes from Mid Miocene to the Early Pleistocene in the epizonal conditions and deposited by means of different stream patterns.

\section{References}

[1] Ashraf, M., Chaudhary, M. N., 1984. Petrology of lower Siwalik rocks of Poonch area: Kashmir Journal of Geology, 2: 1-10.

[2] Baig, M.S., Lawrence, R.D., 1987. Precambrian to early Paleozoic orogenesis in the Himalaya: Kashmir Journal of Geology, 5: $1-22$.

[3] Chaudhri, A. R., Mahavir, S., (2012). Clay minerals as climate change indicators. American Journal of climate, 1:231-239.

[4] Deer, W. A., Howie, R. A., Zussman, J., (1966). An introduction to the rock-forming minerals. Longman group, London, $528 \mathrm{pp}$.

[5] Garzanti, E., Critelli, S., Ingersoll, R.V., (1996) Paleogeographic and paleotectonic evolution of the Himalayan Range as reflected by detrital modes of Tertiary sandstones and modern sands (Indus transects, India and Pakistan). Geological Society of America Bulletin, 108: 631-642. composition of some sediments from the Pacific Ocean off the California coast and the Gulf of California: Geological Society of America, Bulletin, 60: 1785-1808.

[7] Hugget. J. M., Gale, A. S., Clauer, N., (2001). The nature and origin of non-marine $10 \AA$ green Clays from the late Eocene and Oligocene of the Isle of Wight (Hampshire basin), UK. Clay Minerals, 36: 447-464.

[8] Kübler B. 1967. La cristallinité de l'illite et les zones tout a fait superieures du métamorphisme. In: Étages tectoniques, Colloque de Neuchâtel 1966, A La Baconniere, Neuchâtel, 105-121.

[9] Kübler B. 1968. Evaluation quantitative du métamorphisme par la cristallinité d l'illite. Bulletin, Centre Rech. Pau--S.N.P.A. 2: 385-397.

[10] Kübler, B., (1984). Les indicateurs des transformations physiques et chimiques dans la diagenèse, température et calorimétrie. in: "Thermobarométrie et barométrie géologiques", M. Lagache ed., Society of France Minéralogy and Cristallogrphy, Paris, 489-596.

[11] Monalisa and Khawaja, A.A., 2004. Structural trends and focal mechanism studies in the Potwar area with special emphasis on hydrocarbon exploration: Pakistan Journal of Hydrocarbon Research, 14: 49-59.

[12] Wadia, D. N., (1928). The geology of the Poonch State (Kashmir) and adjacent portion of the Punjab: Geological Survey of India, Memoirs, 51 (2): 185-370.

[13] Yasin, M., (2014). Petrography and Sedimentology of Neogene sediments in Mang and adjoining areas in the Sub Himalayas, Azad Jammu and Kashmir, Pakistan, Unpublished MS Thesis, University of Azad Jammu and Kashmir, Muzaffarabad, pp. 213 